\title{
Legal Issues Associated with High School Expulsion
}

\author{
Yao Suet Yi Sherry ${ }^{1}$, Zhao Danyang, ${ }^{2}$ * \\ ${ }^{1}$ High School, Guangdong Country Garden School, Guangzhou, Guangdong, China \\ ${ }^{2}$ Law School, South China Normal University, Guangzhou, Guangdong, China
}

Email address:

danyang371231@163.com (Zhao Danyang)

${ }^{*}$ Corresponding author

\section{To cite this article:}

Yao Suet Yi Sherry, Zhao Danyang. Legal Issues Associated with High School Expulsion. International Journal of Law and Society. Vol. 3, No. 3, 2020, pp. 91-95. doi: 10.11648/j.ijls.20200303.12

Received: April 23, 2020; Accepted: June 4, 2020; Published: June 16, 2020

\begin{abstract}
Expulsion has been a necessary part of student status management for many high schools, and schools can expel students who violate relevant regulations. But in China there is a lack of legal basis for the procedural guarantee in student expulsion, which inevitably leads to inconsistent standards and procedures in different schools. Considering substantive issues, unclear rules about expulsion have led many abused expulsion in practice. High schools can make rules to manage students, but there is no relevant law that whether high schools have the power of dismissing students. And if high schools can dismiss a student, the scope of expulsion matters is another complex problem. Expulsion is most severe and extreme way to punish students. In practice, high schools determine which kind of actions needs to be punished by themselves. The author finds out some students were dismissed because of some small mistakes. This phenomenon violates Proportionality principle, and students' rights of accepting education are infringed. Besides that, procedures of expulsion in different high schools are different. Some high schools have simplistic procedures when making the decision of expelling or dismissing students, which infringes students' rights. The author sorts out the management authority of high school by the dual approach of entity and procedure, and puts forward personal thinking about the chaos in practice. In view of the incomplete education laws in China, and the improper regulation and enforcement of ordinary high school sanctions. The author analyzes problems on expulsion in high schools based on real-life cases, and provides advice for this problems.
\end{abstract}

Keywords: School Roll Management, Legal Retention Principle, Due Process

\section{Introduction}

Article 28 of China's "Education Law" stipulates that authorities of secondary schools have the right to manage student status. Expulsion is most severe and extreme, among all the ways. On the surface, expelled students lose their student identity in one school, but it is less likely that other similar schools will accept him/her. This means that students have virtually lost their student status at the social level, and their basic right to education is infringed. Obviously, expulsion involves not only serious legal issues, but also complex social issues. However, this issue has not been clearly stated by law in China's ordinary high schools, and thus has caused many problems in practice.

\section{Presentation of Cases and Analysis of Concepts}

\subsection{Case Presentation}

\subsubsection{Case One}

A student took a red envelop, which involves a few thousand $\mathrm{RMB}$, in his teacher's classroom. The teacher discovered the student's theft by checking the surveillance video. After the student acknowledged it, the teacher documented the incident in writing and forward it to his head teacher. Eventually, the Student Office informed the student, his parents, the head teacher, the grade director, and director of the Senior School Student Office to convene a five-party conference, which concluded that the student violated the school's discipline of "Stealing Public and Private Property" and was expelled from the school. After being consulted by the school, the student had to leave the school. 


\subsubsection{Case Two}

The dormitory teacher (teacher in charge of dormitory life affairs) found a student smoking in the dorm. Later, the student was required to write a written report and his head teacher was notified at the same time. In the end, the Student Office notified the student, his parents, the class teacher, the grade director, and the high school student office director to hold a five-party conference, which concluded that the student violated the school's rule of "No Smoking" and was punished with advisory dismissal from the school.

The student's parents refused to accept the dismissal punishment. At the same time, the student overturned his own written introspection and denied the fact of smoking. However, the school management withheld the punishment and forcibly revoked the student's school ID. As a result, the student had to leave the school.

\subsection{Analysis of the Relevant Concepts}

\subsubsection{Differentiation of the Concepts of Expulsion and Advisory Dismissal}

In the above cases, the punishment given by the school administration is somewhat different: one is expulsion and the other is advisory dismissal. It is necessary to distinguish two concepts.

Expulsion is the most severe disciplinary penalty within the school's right to punish students. Compared with expulsion, advisory dismissal is not a punishment, but a way to deal with enrollment. School authority persuades the students choose to drop out school. The advisory dismissal is proposed by the school authority and determined by the students.

The nature of the two concepts is not the same but in practice they are often perceived to be the same. As mentioned in case two, when neither the student nor the parents agreed to be dismissed from the school, the school authority chose to adopt compulsory measures to revoke the student's status. In this case, the "persuasion" in "advisory dismissal" often exists in name only. Students and parents are unable to confront the school. Advisory dismissal has the same consequence as expulsion, and the students' right to education also be seriously violated [1].

\subsubsection{The Legal Nature of Secondary Schools}

In China's education system, ordinary senior high schools have some special features. The "Compulsory Education Law" regulates the teaching management of six years in primary schools and three years in junior high schools. Legal documents such as "Higher Education Law" and "Regulations for the Management of Students in Regular Higher Schools" regulate higher education. High school education is not free and compulsory, so it is not part of compulsory education. And it also not suit the meaning of higher education. Its teaching management can only rely on basic laws such as the Education Law.

Although it is in a relatively vague state in legislation, the authorities of ordinary high schools enjoy the rights of enrollment, management of student status, and issue of academic certificates [2]. Their behavior is consistent with the unilateral and compulsory nature of administrative subjects, and the relationship with students has the characteristics of administrative legal relations [3]. Therefore, ordinary high schools should be an independent administrative subject in teaching management.

\section{Exploration of Substantive Issues}

\subsection{Rule-making Power of Secondary Schools}

According to Article 25 of the "Interim Implementation Measures for the Degree Regulations of the People's Republic of China", degree-granting units may formulate working rules for awarding degrees by their own units. It can be seen that ordinary high schools have the right to award diplomas are entitled to make their own rules (code of conducts) for the management of their degrees, which form part of the school rules [4].

\subsection{The School's Right to Exercise Expulsion of a Student}

On the question of whether ordinary high schools have the right to expel a student, the principle of legal retention is of great significance. The principle of legal retention is based on the principles of democracy, the rule of law, and respect for basic human rights, thus it has a strong influence in the administrative field [5]. Expulsion of students related to students' basic right to education should be based on the principle of absolute retention. In the absence of laws and regulations, ordinary high schools do not have the right to expel or dismiss students [6].

In addition, there has difference the between administrative sanctions and administrative penalties. Administrative sanction is a measure of internal management, an internal negation of disciplinary acts, and it cannot deprive the governed (students) of their external rights. Administrative sanction has six types and all of them belong to the scope of internal negation. They can't interfere the basic right of the citizens [7]. In comparison, the administrative penalty is a state administrative management behavior, which can deprive offenders of their external rights and punish the offenders. The expulsion of students obviously involves the dual rights of students inside and outside the school, which should be a kind of administrative penalty [8]. According to the "Administrative Punishment Law", the types of administrative penalties not specified can only be prescribed by laws and administrative regulations. Therefore, the school's decision to dismiss students is suspected of exceeding its authority [9].

Finally, according to Article 28 of the Education Law, schools are eligible to manage student status, implement rewards or punishment. Article 29 clearly states that "the legitimate rights and interests of educated persons, teachers and other employees". From the law's internal logic that the punishment of students should be based on the premise of not infringing their legitimate rights and interests, and students cannot be treated with extreme punishment such as expulsion. 


\subsection{The Scope of Expulsion}

After referring to the relevant regulations of higher education (colleges and universities), the author puts some personal thoughts about the scope of secondary school expulsion.

Article 52 of the "Regulations for the Management of Students in Ordinary Colleges and Universities" stipulates eight cases of expulsion, including acts that violate the Constitution, that constitute criminal offenses, plagiarism, etc., or other acts that cause serious consequences. It can be seen that expulsion of students as the most severe means of punishment is aimed at serious violations of law and discipline [10]. In practice, colleges and universities strictly apply the punishment of expulsion within the scope of the law [11].

The author believes that although high school education is different from higher education, the "Higher Education Law" regards "high secondary education" as a prerequisite for higher education and high school education is more basic and more educated than higher education. The standard to meet the punishment should not be less severe than that of higher education. Therefore, the author believes that only when the following two conditions are satisfied does the high school have the right to expel or dismiss students, if they have the right of expulsion.

a. The act violates the national criminal law or seriously violates other laws, regulations, and rules. It includes violations of national criminal law, being investigated for criminal responsibility according to law, violations of national law, but not yet constituting a crime or constituting a crime but not being investigated for criminal responsibility according to law, violation of other national laws, regulations and rules, etc.; seriously harming the interests of the country, society and collective Or violate the legal rights and interests of other citizens; seriously disrupt the order of the campus or social order.

b. Students have serious faults subjectively. The degree of student's subjective fault can be judged by students' violations of laws, regulations, and disciplines. The standard of judgment must meet the standard of knowledge of ordinary high school students.

In practice, many high school rules go beyond these limits. Take one of the high school rules mentioned in the previous case (referred to as "the ten disciplines") as an example.

Ten Disciplines of Student code of conduct (from a certain school)

..... Three warnings are converted into a penalized punishment, and three times of penalties are converted into a punishment for probation. If students violate rules again after probation, they will be punished with the advisory dismissal.

Article 9 the development of bad habits is strictly prohibited. It is strictly forbidden to date, to smoke ...... Offenders will be given disciplinary sanctions.

Article 10 Crimes and crimes are strictly prohibited. It is strictly forbidden to steal public and private property, to participate in gambling, to prohibit drug use, to view pornographic, anti-government books, audio-visual products....... Offenders will be expelled.

As mentioned in the previous case, when exercising its administrative power, the school treats the expulsion and advisory dismissal as the same. So, the "advisory dismissal" of Article 9 has the effect of "expulsion". Among the behaviors stipulated by these two articles, only those acts that result in criminal offenses should receive the expulsion from school. Neither dating nor smoking constitutes serious violations of laws and disciplines, and some of them even do not belong to the scope of "bad behaviors". In addition, after probation, violators will be dismissed. The basis for dismissal is not the severity of behavior, but the frequency, which is extremely unreasonable. The school's ten disciplines clearly exceed the school's regulatory limits on matters such as expulsion and dismissal, and undermine students' rights to education.

\section{Exploration of Procedure and Due Process}

Some high schools have simplistic procedures when making the decision of expelling or dismissing students, which has led to more lawsuits. Indeed, procedural issues can also be studied with reference to the regulations of universities. Articles 55, 56, and 57 of the "Regulations for the Management of Students in Higher Education" stipulate the procedures for school disciplinary action, the right of students to make a statement, and the right of defense. With reference to the regulations, the following aspects should be noted in the procedures for expulsion from high school:

a. Students have the rights to state and defend. The school should listen to the student's statement and defense before disciplinary action, and record it on file [12]. After the statement and defense, the student who is disciplined should sign the transcript. If the student refuses to sign, the listener should write the reason for the refusal in the transcript.

b. The process and method of obtaining evidence must conform to the regulations. Evidence cannot be collected in an illegal or improper manner, and confessions cannot be forced or induced, otherwise they shall be excluded.

c. The decision to dismiss a student shall be determined by the principal meeting. The principal's meeting is divided into two types, one is the principal's office meeting, the relevant meeting hosted by the principal while the other is a meeting authorized by the principal and held by the principal or other principal and related departments to resolve specific matters. There must be at least one meeting before the student can be expelled.

In Case 1 which mentioned above, the amount of theft amounted to thousands of RMB, which constituted a criminal offense; the school obtained the evidence properly, and the principal convened a five-party meeting to make a decision. The decision met the requirements in substance and form. In case two, smoking does not reach the severity of substantial dismissal. At the same time, the school only made a disciplinary punishment of advisory dismissal, and 
subsequently forced the student to leave the school without due process. Therefore, this dismissal was not in compliance with the requirements in substance and form.

\section{Suggestions for Improvement}

The author puts forward the following countermeasures in view of the incomplete education laws and regulations in China, the unsatisfactory legal remedy channels for ordinary high school students, and the improper regulation and enforcement of ordinary high school sanctions.

\subsection{Standardize the Disciplinary System and Enforcement Procedures}

First, ordinary high schools should strictly implement due process in accordance with the law, further standardize the disciplinary process, and follow the principles of due process and proportionality [13]. Such as the investigation procedures of the high school management department, the research and decision-making procedures of the principals' meeting, etc., especially when making the punishment that severely affects the student's right to education, such as reaching a verdict to expel a student from the school, shall be supervised by the relevant school department (s), and the hearing shall be a necessary link. Secondly, the application of the punishment power of ordinary high schools should follow the principle of proportionality. When deciding upon a punishment, the school shall ensure that the adverse effects of punishment on students must be kept to a minimum, so that a proper ratio between "purpose" and "means" is maintained.

The exercise of the right of sanction must not impair the legal rights, and the punishment of students must be controlled within the legal scope. For example, when the school deals with cheating in exams, or gender-related violations (cohabitation and sexual behaviors of a male and a female student) and notify the penalties in public, this may infringe on students' right to privacy and reputation. Hence the school must exercise extreme caution.

\subsection{Improve the Legal Relief Mechanism}

First, strengthen the construction of student appeal system. In terms of institution setting, education administrative departments and high schools at all levels should establish specialized and independent complaint acceptance agencies and be equipped with sufficient professionals [14]. In terms of legislation, the education legislative department can issue specific grievance management regulations and implementation methods to clarify the core content of the grievance system, such as the subject of the grievance, the grievance form, and the scope of grievance acceptance, so that students can have laws to follow in grieving [15]. In the implementation process, the school must adhere to strict law enforcement and illegal investigation, and establish a corresponding avoidance system.

Second, improve the education administrative review system and litigation mechanism. First of all, the actions of ordering withdrawal and expulsion should be included in the administrative review channel to further improve the administrative review system. The purpose is to provide a strong institutional guarantee for the resolution of disputes over student status and disciplinary action. At the same time, it is necessary to formulate the review standards for specific high school administrative behaviors that are obviously inappropriate, and strengthen the administrative reconsideration to monitor the inappropriate behaviors. Second, improve the educational administrative litigation mechanism, clarify the qualifications of administrative defendants in ordinary high schools, and strengthen the court's review of the rules for disciplinary sanctions against ordinary high schools. Finally, improve the litigation mechanism. When the ordinary high school punishment right infringes the student's right of reputation and the right to know or privacy in procedure or entity, students can protect their legitimate rights and interests through litigation.

\section{Conclusion}

Although high school is in the blank area of education legislation, if the high school considers expulsion or advisory dismissal, the substantive and procedural conditions must be satisfied initially. To achieve a balance between the right to punish students in ordinary high schools and the right to receive education, and to ensure the legitimate rights and interests of students, it is necessary to standardize the punishment system and enforcement procedures, while constantly improving the legal relief system. Only in this way can we reduce the disputes between schools and students, so that the high school student management will become truly systemized and the possible loopholes will be removed.

\section{References}

[1] Dai, Guoli, and Ma, Hemin, "The Chaos and Legal Regulations of Dismissing Students from High School," in Journal of The Chinese Society of Education, vol. 10, pp. 62-67, 2016.

[2] Ye, Aizhen, "Viewing the construction of college examination management system from the disciplinary punishment of examination," in Examination Research, vol. 4, pp. 3-8, August 2012.

[3] Ma, Huanling, "Disciplinary Disputes of College Students and Their Settlement," an article for master's degree, East China Normal University, 2007.

[4] Shen, Suping, "Education Law: Principles, Norms and Applications,” Education Science Press, 2019.

[5] Liu, Wenfeng, "Does the University Have the Right to Set Punishment for Expulsion?" in Higher Education Exploration, vol. 5, pp. 27-30. 2009.

[6] Zhou, Weidong, "Constitutional Review of Mandatory Handling in High School," Southeast University, 2018.

[7] Liu, Yuanfeng, "Legal issues associated with Expulsion and Advisory Dismissal," in Lawyer corpus of the 5th China Lawyers Forum, pp. 793-795, 2005. 
[8] Xu, Jian, "Discussion on the Legal Nature of Punishment in Higher Education," in Journal of East China Normal University (Educational Sciences), vol. 2 pp. 32-41, 2020.

[9] Su, Zhong, "Research on the Examination of Illegal Regulations in Colleges and Universities," in China Education, vol. 8, p23, 2012.

[10] Li, Nairong, "On the Legal Application and Procedural Reflections on Expulsion from Colleges and Universities," in Contemporary Education Practice and Teaching Research, vol. 9, pp. 102-103, 2014.

[11] Yin, Xiaomin, "Research on the Rule of Law in Higher Education Student Management," Zhejiang University Press, 2018.
[12] Dai, Guoli, "Legal Control of the Educational Disciplinary Power in Colleges," in Oriental Law, vol. 2, pp. 129-137, 2019.

[13] Shen, Suping, and Hao, Panpan, "A Review of the Legality and Rationality of the Regulations on Dismissal of Students from Colleges and Universities-Analysis Based on the Regulations of 8 ' 985 ' Universities," in Beijing University Education Review, pp. 53-62 and 188, vol. 15, 2017.

[14] Zhu, Mang, "A Study on the Legal Attribute of College Regulations," in China Legal Science, vol. 4, pp. 140-159, 2018.

[15] He, Shanping, "Discussion on the Legitimacy of Expulsion," in Education Science, vol. 2, pp. 42-45, 2003. 